\title{
Dimensions of Service Quality in Badan Penyelenggara Jaminan Sosial Kesehatan Kota Dumai Theovanni Yolanda Evelin ${ }^{1}$, Hildawati ${ }^{2}$ \\ ${ }^{1,2}$ College of Administration Lancang Kuning theovanni.yolanda@yahoo.com
}

\begin{abstract}
A business organization as a producer is expected to be able to create products that can satisfy the wants and needs of consumers. Companies that are unable to satisfy consumers will be automatically displaced from competition. However, it is ironic that, in contrast to technology and an increasingly developing era, the implementation of public services is still not in accordance with the needs and desires of the community. The progress of the times has made the order and dimension of community values in various fields more complex. This means that public service activities are currently not ready to respond to community demands. This research was conducted at the BPJS Kesehatan Office in Dumai City. Data sources can be primary and secondary data. Judging from its purpose, this research is a descriptive study, which explains the quality of BPJS Kesehatan Kota Dumai services in conducting services from the point of view of consumers. The results showed that the service at the BPJS Kesehatan Kota Dumai Office still had a number of problems in the service process. In this study, author provide advice to provide training services to employees of the BPJS Kesehatan Kota Dumai and the company is expected to be more responsive to criticism and suggestions from the community to be able to serve the community better.

Keywords: quality, service, community
\end{abstract}

JEL $\quad:$ M30

DOI $\quad: 10.24002 /$ kinerja.v21i2.948

Received : 01/29/2020 Review : 02/08/2020 Final Version : 07/10/2020

\section{INTRODUCTION}

A business organization as a producer is expected to be able to create products that can satisfy the wants and needs of consumers. Companies that are unable to satisfy consumers will be automatically displaced from competition. That's why each company continues to innovate to create quality products. 
The quality of a product is a benchmark for consumers to use the product. Consumers certainly want to get products that are comparable to the costs incurred for these products. The quality of a product can describe the parameters of how well a product can satisfy the needs or desires of consumers. Good quality products or services will get better market opportunities and are valued more highly than similar goods of lower quality.

Badan Penyelenggara Jaminan Sosial (BPJS) Kesehatan is a Public Legal Entity that reports directly to the President and has the task of organizing national health insurance for all Indonesians, especially for goverment employees, goverment employees pension recipients, and the TNI / POLRI, veterans, pioneers of independence with their families, and other business entities or ordinary people. In other words, BPJS Kesehatan is a government health insurance agency for all Indonesian people.

Based on Undang-Undang No. 25 of 2009 concerning Public Services, public services are activities or a series of activities in the framework of meeting service needs in accordance with statutory regulations for every citizen and resident of goods, services, and / or administrative services provided by the organizer public service. This means that getting good service is the right of everyone who is protected by law.

However, ironically, in contrast to technology and an increasingly evolving era, the implementation of public services is still not in accordance with the needs and desires of the community. The progress of the times has made the order and dimension of community values in various fields more complex. This means that public service activities are currently not ready to respond to community demands. The progress of the times and the shift in values in society are challenges for the public service providers to continue to innovate and improve their quality so that they can continue to survive.

\section{LITERATURE REVIEW}

\subsection{Services}

In economics, business or service is an economic activity that can be seen from the interaction with consumers or property, but not related to property rights' transfer. According to Lovelock and Wright in Sudarso (2016: 31), service is described as a product process, where a process involves input and transform it as output. According to Hardiyansyah (2018: 59), public services must be as expected:

1. Rights and obligations for aid providers must be clear and recognized by each party;

2. Arrangement of any general needs that are adjusted to the needs and needs of the community for licensing needs in accordance with fixed requirements;

3. The quality, process and results of public services must be endeavored so that they can provide accountable security, comfort and legal certainty. 


\subsection{Quality}

Both in public and private sectors, a company is required to provide quality services for customers. Product quality is a benchmark for customers to use the product. The quality of products can describe how well the product can satisfy customers.

According to Norman and Trilestari in Hardiyansyah (2018:48), if we want to be successful in providing quality service, we must understand the characteristics of service first, as:

1. Service is tangible, service is very contradictory with merchandise.

2. Service actually consists of real actions and is an influence which is a social action.

3. Production and consumption of services cannot be clearly separated, because in general the same event occurs in the same place.

Based on the theory put forward by Heizer and Render in Wibowo (2017: 113), quality is a standard of how well a product or service is able to meet customer needs. Meanwhile, according to the theory put forward by Russel and Taylor in Wibowo (2017: 113), quality is the capability of products and services to satisfy certain needs from inside and outside.

\subsection{Dimensions of Service Quality}

According to Wibowo (2017: 113), to understand the meaning of quality, it can be seen from the perspective of producers and consumers. In the customer's mind, quality has many dimensions and may be applied at one time. Russel and Taylor in Wibowo (2017: 115) separate the customer's perspective on products and services. The dimensions of service quality are indicated by the following matters:

1. Time and timeliness, shows how long the customer must wait for service and completed in time.

2. Completeness, indicating whether what the customer is requesting is provided.

3. Courtesy, showing how customers are served by workers.

4. Accessibility and convenience, shows how easily customers get service.

5. Accuracy, shows whether the service runs well at all times.

6. Responsiveness, shows how well the company reacts to unusual situations.

\section{METHODOLOGY}

This research was conducted with the aim of describing the quality of services at BPJS Kesehatan in Dumai City from the consumer dimension. This research was conducted at the BPJS Kesehatan Office in Dumai City. Data sources can be primary and secondary data. The data collection was carried out at the BPJS Kesehatan Office in Dumai City. Judging from its purpose, this research is a 
descriptive study, which explains the quality of BPJS Kesehatan services in conducting services from the point of view of consumers.

\section{RESULT AND DISCUSSION}

Based on the focus of the research problem, to measure the quality of services at the Dumai City Health BPJS, the authors use the theory put forward by Russel and Taylor in Wibowo (2017: 115) about the dimensions of service quality, namely Time and timeliness, Completeness, Courtesy, Accessibility and convenience, Accuracy, and Responsiveness. Following is an explanation of the 6 dimensions of service quality.

\subsection{Time and timeliness}

Indicates how long the customer must wait for service and be completed in time. In BPJS Kesehatan Kota Dumai Office, the employees are working well. Existing facilities and infrastructure really help the service process. But it is still considered not timely because the service is rather long.

\subsection{Completeness}

Indicates whether what the customer is requesting is provided. The completeness of work that is always ready to serve every request is the hope of society. BPJS Kesehatan Kota Dumai Office is considered to be complete enough to serve the participants. But it still needs improvement in order to provide faster service.

\subsection{Courtesy}

Shows how customers are served by workers. Based on observations, employees of BPJS Kesehatan Kota Dumai are very friendly and polite in serving the people who come from arrival to return.

\subsection{Accessibility and convenience}

Indicates how easily customers get service. The location of the BPJS Kesehatan Kota Dumai in the city center is very strategic and makes it easy for the community to deal with it.

\subsection{Accuracy}

Indicates whether the service is going well at all times. The employees of the BPJS Kesehatan Kota Dumai are considered to have been quite thorough in their work. However, sometimes there are still some problems in the field that are annoying and take a long time. 


\subsection{Responsiveness}

Shows how well the company reacts to unusual situations. BPJS Kesehatan Kota Dumai is considered still weak in overcoming the problems that come. They are still slow in responding to participant claims that require funds disbursement.

\section{CONCLUSION}

Each quality dimension's indicators is an inseparable unit. Because each of them is needed and sought by customers. More many indicators can be completed, customers will be satisfied with the company's services.

\subsection{Managerial Implication}

Based on the results of the study, the quality of services at the BPJS Kesehatan Kota Dumai Office viewed from the dimensions of service quality from the perspective of consumers according to Russel and Taylor in Wibowo (2017: 115) can be quite good. But it still has obstacles in processing complaints or requests from the public. Even though it is easy to reach and employees are friendly, the services that are the main work still need improvement.

Author provide suggestions that might be used as input to improve future services, including by providing training for employees of the BPJS Kesehatan Kota Dumai to be able to serve better. In addition, the company is expected to be able to respond to criticism and suggestions from the public who come as material for introspection. Because within the scope of management, criticisms and suggestions that come from outside the organization are important inputs to build a better organization.

\subsection{Limitation and Future Study}

This research has not presented accurate data as material of analysis, because author have not got permission from supervisor to carry out the observations to research location. In future studies, author will allow and add data required to measure the quality of BPJS Kesehatan services in Dumai City more accurately.

\section{REFERENCES}

Wibowo, 2017. Manajemen Kinerja. 5th ed. Depok : PT. RajaGrafindo Persada.

Hardiyansyah. 2018. Kualitas Pelayanan Publik (Konsep, Dimensi, Indikator dan Implementasinya). Yogyakarta: Penerbit Gava Media.

Sudarso, Andriasan. 2016. Manajemen Pemasaran Jasa Perhotelan (Dilengkapi dengan Hasil Riset pada Hotel Berbintang di Sumatera Utara). Yogyakarta: Deepublish.

B. P . Sitepu, 2016. Pedoman Menulis Jurnal. Bandung : PT. Remaja Rosdakarya.

Undang-Undang Nomor 25 Tahun 2009 tentang Pelayanan Publik. 